\title{
Effect of Catchment and Hydrology of Ancient Dalpatsagar Reservoir on Water Resources of Jagdalpur City, Bastar, India
}

\author{
Adikant Pradhan*, S.K. Patil, D.K. Marothia, T. Chandrakar, \\ S.K. Nag and S.C. Mukherjee
}

S. G. College of Agriculture and Research Station, IGKV, Jagdalpur, Bastar (C.G.) 494001, India

*Corresponding author

\section{Keywords}

Catchment

hydrology,

Rainwater

management, Water

conservation,

Dugwell recharge

Article Info

Accepted:

12 December 2018

Available Online:

10 January 2019

\section{A B S T R A C T}

Topographical and other constraints further limit the utilizable quantity of water which rapid growth in the demand for water due to rise in population, increased pace of urbanization and industrialization is posing serious challenges in providing food and water security. King Dalpatdev Kaktiya was a king from the Kakatiya dynasty who made reservoir in north-west part of Jagdalpur and named Dalpatsagar is now being affected badly by city expansion and draining sewage into the reservoir. Earlier the people settled at top of the toposequence which supported for run off flow but expansion of city on catchment areas created problem. For assessing effect of Dalpatsagar on water resource, the data on 121 dugwells and borewells were taken under consideration of depth pre (April-May) and post (October-November) monsoon observations during 2015-16 along with locations in Jagdalpur city. In which 121 dugwells, 60 as dirty water, 12 drying in pre monsoon period and 36 for drinking purpose were noticed under intensive observations during 2015-17. Maximum dugwells were recorded in Gandhinagar ward (17), followed by Dantewshari ward (15), Ambetkar ward (15) and Shyama Prasad Mukherjee ward (11) and Ravindrnath Tagore ward (9) in draining area of city watershed demarcated as recharge zone due to stagnation of water in two storage structures namely Dalpatsagar and Ganga Munda aligned in way of natural drainline. Water table of borewells allows explaining $4 \%$ variability in depth which was in between 100 to 150 feet bgl (below ground level) but linear trend highly variable around the line. Standard residuals versus depth of tube wells were also widely distributed in depth for pumping water, water table plotted against standard residuals was found between 80 to 100 feet bgl, on other hand, predicted water table on standard residuals ranged negatively and positively in between 80 to 100 feet $\mathrm{bgl}$ i.e. pumping water at common depth of the Jagdalpur city. In future, water availability will be in prime focus under dwindling rainfall if hydrological assessment is not done on management catchment and command areas. Turbidity, $\mathrm{pH}$, conductivity, alkalinity, chloride, calcium, iron, biological oxygen demand, chemical oxygen demand were higher than allowable limit in August 2015 whereas nitrate, total hardness $\left(\mathrm{CaCO}_{3}\right)$, $\mathrm{Mg}$, fluoride, sulphate, TSS, residual $\mathrm{Cl}$ and dissolved oxygen were less than allowable level during April 2016. 


\section{Introduction}

Water is a key natural resource which is fundamental to life, livelihood, food, energy and water security and sustainable development. The average annual precipitation for India is about 4000 billion cubic metres (BCM). Average annual water availability for the whole country is about 1869 BCM (GOI, 2016). Topographical and other constraints further limit the utilizable quantity to about $1123 \mathrm{BCM}$. Rapid growth in the demand for water due to rise in population, increased pace of urbanization and industrialization is posing serious challenges in providing food and water security. Challenges in water management in India are to meet water needs, ensure environmental rejuvenation and sustainable development. A country is categorized as 'water stressed' when available freshwater per capita per year is below $1700 \mathrm{~m}^{3}$ and 'water scarce' if it falls below $1000 \mathrm{~m}^{3}$. India's current average per capita water availability is $1410 \mathrm{~m}^{3} /$ year which are likely to drop to $1154 \mathrm{~m}^{3} /$ year by the year 2060 with a projected population of 1620 million (GOI, 2016). Water resources management requires proper management of rainfall, stream flow and other variables.

India has a monsoon type of climate and about $80-90 \%$ of the annual river flows occur during four monsoon months. Hence, it is important to conserve monsoon flows for meeting the demands in the lean season. Transfer of water from surplus to deficit basins through inter basin water transfer is an attractive option to meet large water demands in a sustainable manner. Groundwater is a cheap and fairly dependable source of water. It has contributed immensely to increase the irrigated area and raise farmer's income. Groundwater is helpful buffer when rainfall is deficient or in drought prone areas. Access to safe and clean drinking water is one of greatest challenges that India is facing.
Among the 5,842 administrative units assessed for groundwater availability in India, 80 units are over-exploited, 169 critical and 523 semicritical. Around $60 \%$ of all districts have issues related to either availability and/or quality of ground water (Planning Commission Five Year Plan, 2013).

Wetlands are significant reserves for biodiversity and water resources from life support to cultural heritage. In India, agricultural and urbanization in cities of the country has vitiated the wetland dynamics along with decadal changes into ecosystem reducing and degrading the catchment and its associated wetlands. Much of this loss has occurred as catchment has been converted into production of crops.

Bastar region was known as Dandkarnaya, "Kaantaar" and "MahaKaantaar" during Ramanaya, Mahabharat and Gupta period, respectively. Dandkarnya was a part of Ashmak Mahajanpad (600 to 321 BC) situating south of Vindhyaan mountain having capital "Potali", whereas Bastar was part of "Atwik Janpad" as independent province during Maurya dynasty. Every dynasty developed water security system that is why Bastar kingdom also developed the concept of water conservation and supply for domestic as well as agricultural use. King Dalpatdev (1736-1772 A.D.) planned to harvest rain water in low lying area digging big reservoir near palace on earlier existing three dug wells namely Bade Baawali, Saan Baawali and Tulsi Baawali were converted into Dalpatsagar reservoir with help of villagers through "Rasool system" i.e. only meal arrangement for them which was common practice during those time. King Dalpatdev Kaktiya was a king from the Kakatiya dynasty who made reservoir in north-west part of city constructing $5 \mathrm{~km}$ long and 6 metre high earthen bund east to west barrier and top was developed as a road which is still used for 
transport from palace to Kaalipur by public. Shiv temple at middle of reservoir was also constructed by King Dalapatdev in 1772 (Figure 1g). In Chhattisgarh state, biggest man made reservoir is Dalpatsagar constructed for conserving rain water and use in social aspects during 300 years back at Bastar kingdom. The focus of our study is the overall impact water harvesting and water resource of the city.

Numerous other factors, including climate, geology, topographical position and basin morphology also play an important role in controlling water quality of aquatic systems (Kratz et al., 1997; Devito et al., 2005b). Increased nutrients, especially phosphorus, have increased the productivity and biomass in fresh waters around the globe (Schindler, 2006).

\section{Morphometric details of Dalpatsagar reservoir}

The water quality of reservoir is vastly influenced the floral composition and water dynamics promotes which various aspects of aquatic system of Dalpatsagar. The reservoir is divided in limnetic zone, euphotic zone and benthic zone with different floral composition. The Dalpatsagar is in the southern side of Jagdalpur city and catchment ranges from Dharmpura to Adawal in east to west and Sargipal to Indrawati river in north to south. Relief is generally low-lying rolling plains toward north to south in catchment areas (Figure 1g).

\section{Hydrology}

Overall, the Dalpatsagar is characterized by a mean summer temperature of $39^{\circ} \mathrm{C}$ and mean winter temperature of $18.5^{\circ} \mathrm{C}$ with annual precipitation is of $1404.80 \mathrm{~mm}$ (Annual Report, 2016) which promotes large amount of flow. Sargipal area creates southern contour with water dividing line in south direction, down side of the contour expands catchment area, which covers Aghanpur and Dharampura as western boundary delineating catchment for reservoir. Centre part of the city (near Maharani hospital) separates east catchment line, the catchment is being disturbed by constructing colonies on the way of runoff flow to Dalpatsagar reservoir; half of the city drains the rainwater as well as untreated sewage water in to reservoir. Source of inflow water is runoff water from south side of city railway station to Dalpatsagar which is nearly $5 \mathrm{~km}$ long and $4 \mathrm{~km}$ wide catchment includes 3450 ha flow mostly occurs through east weir and west weir of reservoir as naturally drains of low lying region of city to meet Indrawati river that is why water was stopped in Dalpatsagar reservoir by embanking mud wall as ridge line to store rainwater.

Runoff is refilling process of reservoir with onset of monsoon every year set the hydrology of reservoir increasing water level upto $4.56 \mathrm{~m}$ in January decreases upto 1.15 metre by May, which is maximum and minimum level of water, respectively. The runoff enters in reservoir the incoming water changes hydrological over the time and influences water storage structures of city.

\section{Drainage system}

Whole comes in depression area of city following contour line which drains a lot of water in natural drainlines of Jagdalpur watershed one direct connecting drain from Gangamuda tank to open cultivated areas of city and Dharampura. A large amount of water comes from this region alongwith sewage water while another drainlines adds significant amount of water in east part of Dalpatsagar reservoir, is the highest amount sewage to decline the water quality. Housing board colony area another responsible sites for draining water and half of the city as from govt. hospital all the flowing as well as 
sewage come to old Narendra Talkies which is having highest quantity of decomposed mud and organics to water body. Due to the contour line differences from ridge to valley as $600 \mathrm{msl}$ to $543 \mathrm{msl}$ is always supported for natural drain to low lying of reservoir.

\section{Morphometric details}

Relief is generally low-lying rolling plains toward north to south in total catchment areas. Wetland morphometry data were cross referenced with recent aerial photographs and corrected for the present wetland area. Land use data were obtained from the District Administration and GIS data base which is based on Komsat imagery NRSC, Hyderabad (Government of India, 2016). Agricultural land use within a $0.75 \mathrm{~km}$ of Northern side is buffer surrounding wetlands. In recent years, there has been increasing concern that the water resources of these river systems may be vulnerable in the context of global climate change (IPCC, 2007; Kundzewicz et al., 2007), which could have considerable implications for the livelihoods and well-being of the people in the region (Eriksson et al., 2009).

\section{Land use}

Various land use system developed after the establishment and storage of water in Dalpatsagar as urban population increased in the catchment of the city resulted more sewage draining into the reservoir because city expansion is faster than restoration of hydrology every year 50 houses are being constructed on average 2000 square feet area under 48 wards (sectoral division of municipal corporation). The water of the reservoir is not used for irrigation purpose but due to seepage adjoining farmlands became marshy and no cultivation is being done, the area now developed as wetland ecosystem. Various developmental activities and human activities triggering on land available in city curbing most vital lands of drainlines to water body that influences the confluences and streams of the city with diversion which directly responsible for water recharge and surface water flow, these all obstacles are now became a big challenge to hydrology of city watershed. Colony development in low lying areas and diversion channels really affects to drains and natural contour lines is being disturbed through leveling, construction of in proper roads to connect these colonies, filling soil in depression done by people. Ultimately this leads to blockage of city drainage and intrusion of rain water into houses falling in drain lines, seepage of houses, cracking due to imbalance of house setting.

The forest area of Sargipal and Lamni park remains intact due to forest comes under forest department; road side plantation somehow remains until road widening is done. Tree cover reservoir is on bund of pathway as avenue plantation with varieties of beautiful tree species like Eucalyptus spp., Terminalia arjuna, Tamarindus indica, Phoenix sylvestris, Acacia nilotica, Mangifera indica, Pithecellobium dulce, Bombax ceiba, Ceiba pentandra, Ficus benghalensis, Ficus religiosa, Ziziphus mauritiana, and Thevetia peruviana.

\section{Demography of city}

Dalpatsagar reservoir is being influenced by city expansion and sewage drains into the reservoir, earlier the population settled at top of the toposequence supports water movement around city but expansion of city on catchment areas created problem for draining sewage with degraded water as mentioned in Table 1. There are substantial differences in hydrologic processes in wetlands associated with naturally landscapes versus cleared agricultural systems (Van der Kamp et al., 2003; Devito et al., 2005a; Redding and 
Devito 2011). The Jagdalpur city's population was just 10128 in 1931 census when Bristishers were ruling over the city as resident, further it was increased linearly till 1991 as decadal growth but suddenly increased in 2001 upto 105442 later decades as it was rose 125483 in 2011(Anonymous, 2011).

\section{Materials and Methods}

\section{Study area}

The Dalpatsagar reservoir is manmade structure located north-west part of city coordinating at $19^{\circ} 5^{\prime} 41 \mathrm{~N}$ latitude and $82^{\circ} 0{ }^{\prime} 43$ E longitude with mean sea level of 563 metre having 137.77 ha (340.44 acres) area of reservoir as per toposheet No. $65 \mathrm{I} / 4,1983$ record. The study site documented herein comprised a city: Jagdalpur watershed and its impacts on water resources of Jagdalpur, Chhattisgarh, India. Meteorological data collected in an open region field located at S.G. College of Agriculture \& Research Station, Jagdalpur. Their elevations are $563 \mathrm{~m}$ above mean sea level and slope gradients ranges 0.8 to $1.2 \%$.

\section{Survey and data collection}

The acquired city map was used to assess the samples on grids, city was divided into wards and were treated as sampling units. The units were individually surveyed the points and observations on dug wells and tube wells were collected considering water depth, diameter of wells along with their uses at present. For survey of water resources of Jagdalpur city, whole city bifurcated into three parts i.e. catchment, drainage and marshy area to study the recharge of structures. Survey was done by personal interview and collected geo-reference data with the help of GPS (Garmin GPS Etrex $30 x)$ at the place of water resource structures. The results are mapped in GIS Software package ArcGIS 10.2 by applying spline interpolation and interpolation techniques are employed to map pre monsoon and post monsoon variation in water of the basin. Collected data during 2015-16 were subjected for statistical analysis using XLStat 2016 for basic and regression analysis (Buchanan, 1983).

\section{Hydrological observations}

Precipitation in the field was measured at the above mentioned meteorological observation station using a storage type rain gauge $(20 \mathrm{~cm}$ diameter). The rain gauge was examined every day at 9:00 am local time (LT) where cylinder was used to measure the volume of water collected in a storage container within the gauge. This result was considered the rainfall amount for each day beginning at 9:00 LT. Daily rainfall data used in this work were read from the original recording on register. Runoff was observed using rectangular 6 weirs $(1.5 \mathrm{~m}$ length $\times 1.0 \mathrm{~m}$ width) continuous connected at western part of reservoir to measure moving out water prior meeting to Indrawati river. Water level recording by piling graduated 2 metre cement pole $(12 \mathrm{~cm} \times 6 \mathrm{~cm})$ at centre of the reservoir. Equation used to calculate flow rate based on the water level was integrated over the time to calculate the runoff using rational formula (Rossmiller, 1980) as $\mathrm{Q}=$ $\mathrm{CiA}$; in which $\mathrm{Q}, \mathrm{C}$, i and $\mathrm{A}$ are the maximum rate of runoff cubic feet per second (cfs), runoff coefficient representing the fraction of rainfall that becomes runoff, rainfall intensity for a duration equal to the time of concentration (in/hr) and drainage area (acres), respectively. The following formula was used to calculate runoff based on water flowing from watershed of city to the reservoir. Water table of each dug well of Jagdalpur city was measured by measuring tape from surface to water table of dugwells to assess their recharging behaviour in different wards during April-May (Pre-monsoon) and October- 
November (Post-monsoon). Wetland morphometry data were cross referenced with recent aerial photographs and corrected for the present map (Photograph $3 \mathrm{a}, \mathrm{b}, \mathrm{c}$ and d).

Physico-chemical analysis like Electrical Conductivity (EC) by electrical conductivity meter (EC meter), $\mathrm{pH}$ by $\mathrm{pH}$ meter, determination of nitrate by spectrophotometer (Cataldo et al., 1975), whereas total hardness $\left(\mathrm{CaCO}_{3}\right), \mathrm{Mg}$, fluoride, sulphate, TSS, residual $\mathrm{Cl}$ and dissolved oxygen (DO) was done with ALPHA Standard Methods (1998). Soil and water samples for nitrogen, phosphorus and potassium content in soil of reservoir were analyzed for $\mathrm{N}$ (modified Kjeldahl methods), phosphorus content (Olsen et al., 1954) and potassium content (Jackson, 1973). Organic carbon of soil was analysed by Walkley and Black (1934).

\section{Results and Discussion}

\section{Effect on dug wells}

Average diameter of wells was 6.27 feet whereas minimum and maximum diameter were 2.00 and 16 feet bgl, respectively higher diameter of old wells are used for community purpose of people.

Dugwells were observed throughout Jagdalpur to know the effect of catchment area, water storage and water movement along the surface gradient. Total 48 wards are present in the city, among these wards, Dalpatsagar, Ramaiya, Indira, Chhatrpati Shivaji, Gurugovind Singh, Rajendra Nagar, Danteshwari, Dindayal, Motilal Nehru, Madan Mohan Malvilya, Shantisagar, Sardar Vallabh Bhai Patel, Jawar Nagar, Sanjay Gandhi, Pt. Sundarlal Sharmaa and Ganga Nagar wards are in catchment area of Dalpatsagar reservoir that directly or indirectly affects of water resources of the city to fulfil increasing water demand of people regularly. Some of the wards like Vijay ward and Pravir ward are in vicinity of reservoir contributed largely to surface as well as ground water. Vijay ward, Netaji Subhash ward, Ramaiya ward, Dalpatsagar ward, Pravir ward showed higher water table in consideration of dugwells as well as tubewells to provide domestic water requirement. Near Indrawati River Pravir ward, Vijay ward, Shivmandir ward, Bhairamdev ward and Vir Sawarkar ward, similarly Ganga Nagar ward, Gandhi Nagar, Sardar Vallabh Bhai Patel ward and Jawar Nagar ward are in around of Ganga Munda tank. According to location water tables were observed in October-November and AprilMay on dugwells as post and pre monsoon, respectively in the Jagdalpur city. This is because of catchment flow starts within contour lines of city which was identified in eighteen century while constructions of Dalpatsagar as natural catchment-storage of rainwater flow from Sargipal and Railway colony which is confined a natural ridge delineating the catchment of Dalpatsagr extending it Sunderlal Sharma ward to Guru Govind Singh ward as upstream boundary gradually narrow down toward Dalpatsagar till Indrawati river that is why the reservoir was constructed at the place. Meanwhile movement of rainwater on surface configuration, water gets retain, refill and recharge water resource depend on their retention period and monsoon at particular points. Many obstacles like building, diversion narrowing down drainage found in flow direction leading to water logging in the city as a result stagnation of water and intrusion into houses is common problem during rainy season (Nyabeze, 2004).

Water table of pre-monsoon and post monsoon observation of dugwells were recorded by surveying wards throughout Jagdalpur city during October-November 2016 and AprilMay 2017. The water table of pre monsoon ranged from 0.00 to 20.84 feet bgl whereas 
post monsoon water table ranged from 1.70 to 40.68 feet bgl showed wide differences in water table which was directly proportionate to depth of dugwells (Figure 1a and b). Mean depth of dugwell was 25.39 feet bgl preferred by users to mitigate pre-monsoon and postmonsoon shortage of water maintaining average diameter of dugwells (6.27 feet bgl). Pre-monsoon table of water drastically changed due to recharge pattern working for maintaining table but area fall near the perennial water bodies showed rising water table. The wards near to Dalpatsagar reservoir and Ganga munda pond maintained the water table as seen in Subhash Chandra ward (4 and 13 feet bgl in feet bgl in pre and post), Ramaiya ward (3 and 8 feet bgl in pre and post), Danteshwari ward (6 and 15 feet bgl in pre and post), Gandhi Nagar ward (2 and 6 feet bgl in pre and post), Ganga Nagar ward (7 and 20 feet bgl in pre and post), whereas old pond situated near Mother Teresa Ward (6.01 and 15.77 feet bgl in pre and post), Rajiv Gandhi (5.97 and 15.66 feet bgl in pre and post) and Shantinagar ward (7.63 and 20.03 feet bgl in pre and post) which is recharged automatically due to depression and large quantity of water infiltrate in low lying area even the area occupied by building construction and settlement near the pond. River side wards Pravir ward (11.30 and 29.67 feet bgl in pre and post) and Vir Sawarkar ward (11 and 31 feet bgl in pre and post) did not show much change in water table as compared to remaining wards of the city (Figure 1a and d).

Data on 121 dugwells were recorded on depth, pre and post area, monsoon observations alongwith locations in Jagdalpur city. Among 121 dugwells, 60 as dirty water, 12 drying in pre monsoon period and 36 for drinking purpose were noticed under intensive observations. Maximum dugwells were recorded in Gandhnagar ward (17), followed by Dantewshari ward (15), Ambetkar ward
(15) and Shyama Prasad Mukherjee ward (11) and Ravindrnath Tagore ward (9) in draining area of city watershed demarcated as recharge zone due to stagnation of water in two storage structures namely Dalpatsagar and Ganga Munda aligned in way of natural drainline. Meanwhile flow of rainwater recharge dugwells due to location (Figure $1 \mathrm{c}$ and $\mathrm{d}$ ). This is the only reason for higher number of dugwells were found in these wards rising water table throughout year but some of wells connecting with sewage and dirty water reduced drinking and domestic water use in localized manner. The depth of dug wells divided in categories of 0-10, 10-20 and 20-30 feet bgl, out of these categories, 0-10 feet bgl depth dugwells were less in number, 10-20 feet bgl had 17 dug wells nearer perennial storage (Dalpatsagar and Ganga Munda), 30 feet bgl onwards depth were very less.

In wards, drinking water resource is dwindling surface storage even after having 121 dugwells found across the Jagdalpur city; most of the dugwells are polluted by sewage drain or surface movement from off sides. Drinking purpose usage of dugwells among city dwellers were in finger count, 32 dugwells were in drinking use located in Pravir ward (2), S.P. Mukherjee ward (7), Ganganagar ward (7), Chandra Shekhar ward (2), Ravindranath Tagore ward (6), Ambetkar ward (6), Mother Teresa ward (1) and Madan Mohan Malviya ward (1). Two types of pollution occurred in dugwells reducing water quality i.e. sewage entry and iron contamination. Dirty water entry was found in Vijay ward, Shubhas ward, Indira ward, Vir Sawarkar ward, Bhagat Singh ward, S.P. Mukhejee ward, Chandrashekhar Azad ward, Shantinagar ward, Mother Teresa ward, Rajiv Gandhi ward and Gandhinagar ward. Dugwells of these wards were located near to sewage or domestic dispersing region that was the reason dugwells were contaminated whereas the same wards remaining dugwells 
are used for drinking purpose. It means the drainage of sewage water would properly directed toward treatment plants may increase the quality water resource of the city (Marothia, 2007).

Drying of dugwells (Pre monsoon: April May) was common in summer due to insufficient depth coupled with less recharge. The water supply system has been developed by Municipal Corporation that is why people are not interested to maintain dugwells regularly. The dugwells are almost in dead condition, even dugwells are not supported for ground water recharge which was earlier feasible to draw water but now water table went down. In this regard, Vijay ward, Civil line ward, Bhagat Singh ward and Chandra Shekhar Azad ward were commonly counted as dry well area due to locational disadvantage.

Observations of dugwells were recorded pre and post monsoon water table alongwith depth. Maximum depth was noticed 61 feet bgl and minimum depth was 6.60 feet bgl while average depth was 25.24 feet bgl with standard deviation of 14.04 feet (Fleig et al., 2006). Pre monsoon maximum, minimum and average water table depth were 20.679, 2.03 and 7.65 feet bgl, respectively from all point with standard deviation of $4.239\left(\mathrm{R}^{2}=0.735\right)$. In case of post monsoon depth maximum and minimum 57.56 and 5.61 feet bgl, respectively whereas average water table was 22.27 feet $\operatorname{bgl}\left(\mathrm{R}^{2}=0.828\right)$.

Depth allows explaining $73.5 \%$ variability of post monsoon water table of dugwells but it was increased $82.8 \%$ in pre monsoon water table of dugwells, linear trend was observed high variability around the line showing variation in location distance of the wells from water storages (Figure 1). Standard residuals versus post monsoon water table were below the zero and negatively deviated i.e. sharp went down of water table with post monsoon period, but pre monsoon water table rose. Post monsoon water table ranged upto 12 whereas pre monsoon was upto 40. Similar effect observed in SODIS (1997) with dug wells.

Actually depth of dug wells against standard residuals in post and pre monsoon water table were mostly negative which was highly variable in both pre and post monsoon but pre monsoon showed higher amount of water. Predicted depth versus standard residuals showed some variation in post monsoon consistently ranged 10 to 40 where pre monsoon depth increased the water table. Predicted depth of wells were linear to actual depth in case of post and pre monsoon water table but more linear with pre monsoon water table in standard versus observational depth was negative in pre and post monsoon but it was increased in pre monsoon water tables. Standard residuals versus depth in validation set showed positive change in post monsoon water table of all observed dug wells and it was just reverse in pre monsoon. Pumping of water from 117.50 average depths was noticed deviation of 18.45 feet bgl in the city location, whereas minimum depth for pumping was 58.50 feet bgl. Average pumping depth of 84.47 feet bgl showed standard deviation of 12.21 feet bgl depth water table (Sangodoyin, 1990) (Fig. 2).

\section{Effect on tube well}

Ground water status was also assessed by taking observation on tube well location with total depth along with ward wise pumping depth (Datta and Tyagi, 1996). Total 63 tube wells were recorded in 48 wards and 17 feet was minimum in Ganga Nagar ward while 300 feet maximum in Mother Teresa ward with average depth found in 98.21 feet water table (Figure 3) in Jagdalpur city (Ghosh and Dutta, 2012) 
Table.1 Population and its impact on water of Dalpatsagar reservoir

\begin{tabular}{|c|c|c|c|c|}
\hline Year & Population & $\begin{array}{c}\text { Population } \\
\text { Increasing rate (\%) }\end{array}$ & $\begin{array}{c}\text { Annual family } \\
\text { expansion (No.) }\end{array}$ & $\begin{array}{c}\text { Draining water } \\
\text { (litres/month) }\end{array}$ \\
\hline $\mathbf{1 9 3 1}$ & 10128 & - & - & - \\
\hline $\mathbf{1 9 4 1}$ & 11304 & 11.61 & 130.67 & 19600.00 \\
\hline $\mathbf{1 9 5 1}$ & 13793 & 18.05 & 276.56 & 41483.33 \\
\hline $\mathbf{1 9 6 1}$ & 20412 & 32.43 & 735.44 & 110316.67 \\
\hline $\mathbf{1 9 7 1}$ & 31344 & 34.88 & 1214.67 & 182200.00 \\
\hline $\mathbf{1 9 8 1}$ & 51286 & 38.88 & 2215.78 & 332366.67 \\
\hline $\mathbf{1 9 9 1}$ & 66154 & 22.47 & 1652.00 & 247800.00 \\
\hline $\mathbf{2 0 0 1}$ & 105442 & 37.26 & 4365.33 & 654800.00 \\
\hline $\mathbf{2 0 1 1}$ & 125483 & 15.97 & 2226.78 & 334016.67 \\
\hline
\end{tabular}

* Annual Report, Municipal Corporation (2011)

Table.2 Physico-chemical properties of reservoir water during 2017

\begin{tabular}{|l|c|c|}
\hline \multicolumn{1}{|c|}{ Parameter } & Observed value & Standard value \\
\hline Turbidity (NTU) & 0.26 & 5.00 \\
\hline pH & 7.09 & $6.5-8.5$ \\
\hline Electric conductivity (uS) & 0.33 & $0.50-3.00$ \\
\hline Alkalinity (mg/litre) & 18.00 & 200.00 \\
\hline Chloride (mg/litre) & 1171.00 & 250.00 \\
\hline Calcium (mg/litre) & 36.02 & $1-135$ \\
\hline Iron (mg/litre) & 7.01 & $5.5-8.2$ \\
\hline Biological Oxygen Demand (mg/litre) & 7.40 & 5.00 \\
\hline Chemical Oxygen Demand (mg/litre) & 0.64 & 10.00 \\
\hline
\end{tabular}

Table.3 Nitrogen, phosphorus and organic carbon in Dalpatsagar reservoir

\begin{tabular}{|l|c|c|c|}
\hline \multicolumn{1}{|c|}{ Place of sampling } & $\mathbf{N}(\mathbf{k g} / \mathbf{h a})$ & $\mathbf{P}_{\mathbf{2}} \mathbf{O}_{\mathbf{5}} \mathbf{( k g / h a )}$ & Organic carbon $\mathbf{( \% )}$ \\
\hline Baba rakhwar & 387.60 & 17.95 & 0.68 \\
\hline Jada Tarae & 512.40 & 18.45 & 1.03 \\
\hline Rani ghat & 642.50 & 16.55 & 2.24 \\
\hline Mundara Dhipka & 650.00 & 19.92 & 2.93 \\
\hline Moti Talab & 764.80 & 19.15 & 4.91 \\
\hline Balaji Mandir & 802.40 & 35.91 & 3.42 \\
\hline Shiv mandir & 758.60 & 16.55 & 4.00 \\
\hline Old Narendra & 850.60 & 53.86 & 6.09 \\
\hline Ram Mandir $($ nala) & 675.20 & 89.76 & 3.77 \\
\hline Housing board & 598.80 & 21.35 & 2.17 \\
\hline Ram Mandir & 671.60 & 22.65 & 4.07 \\
\hline
\end{tabular}


Fig.1 a. Depth variation of open wells, b. Depth of bore wells, c. Pre-monsoon water depth, d. Pre-monsoon water depth of open wells, e. post-monsoon water depth of open wells, f. City ward map g. settlement of the city and h. Contour map of Jagdalpur city

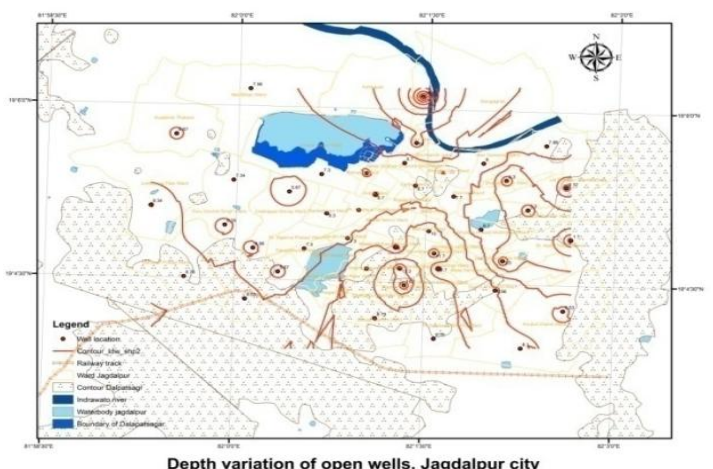

a.

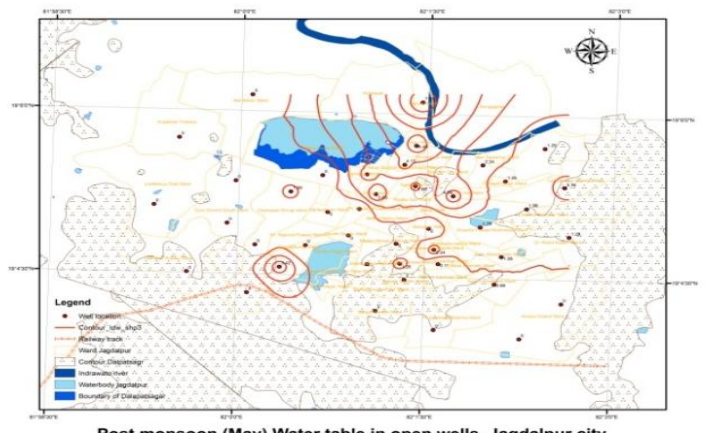

c.

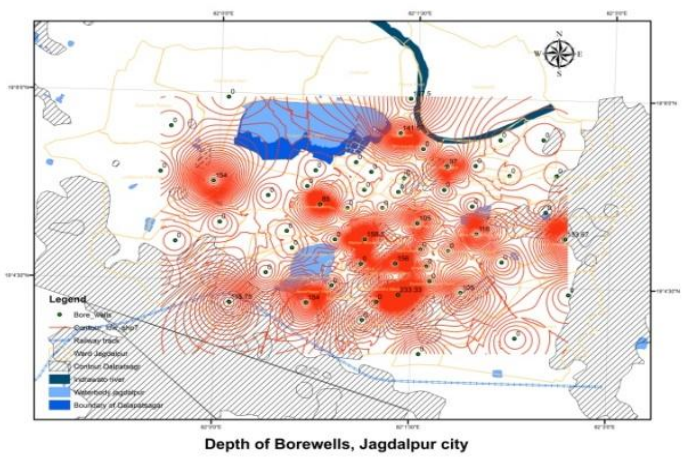

e.

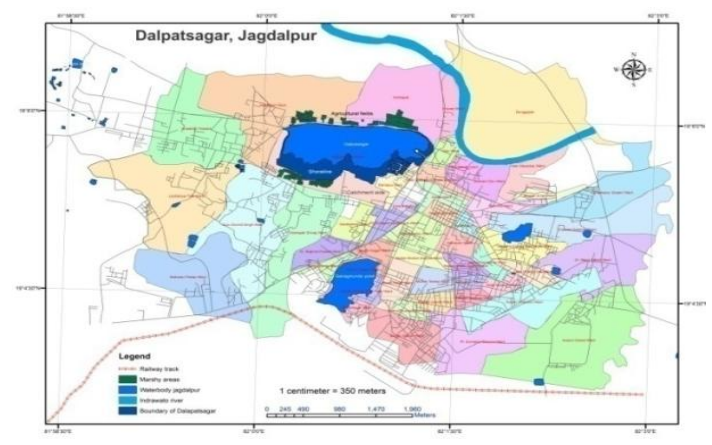

g.

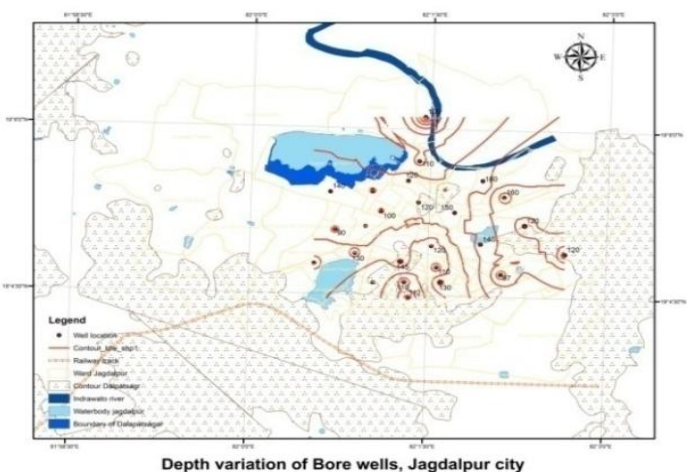

b.

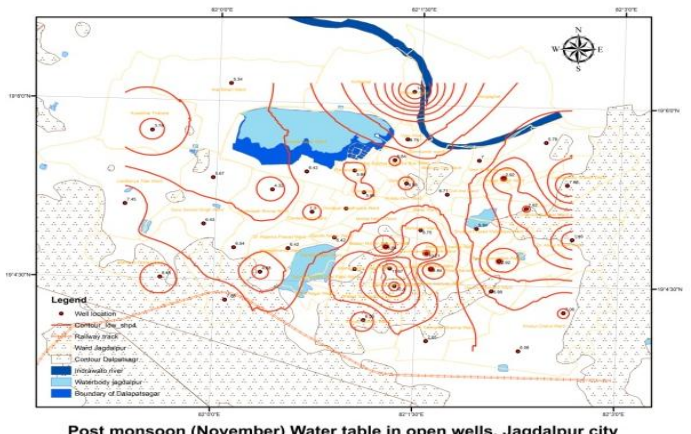

d.

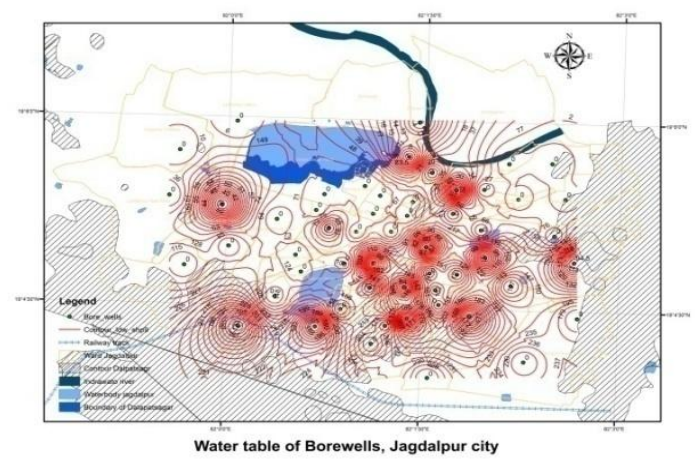

f.

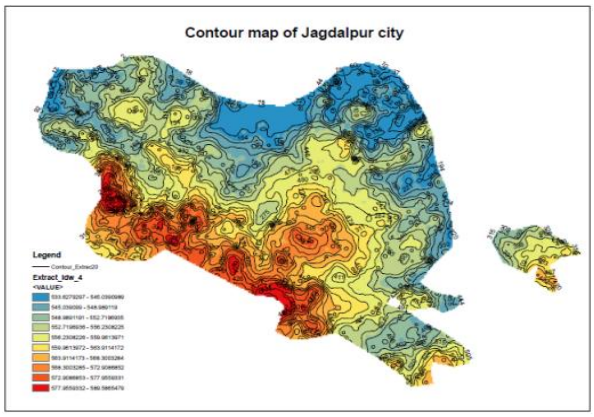

h. 
Fig.2 Ward wise water depth variation of open dug wells at Jagdalpur city

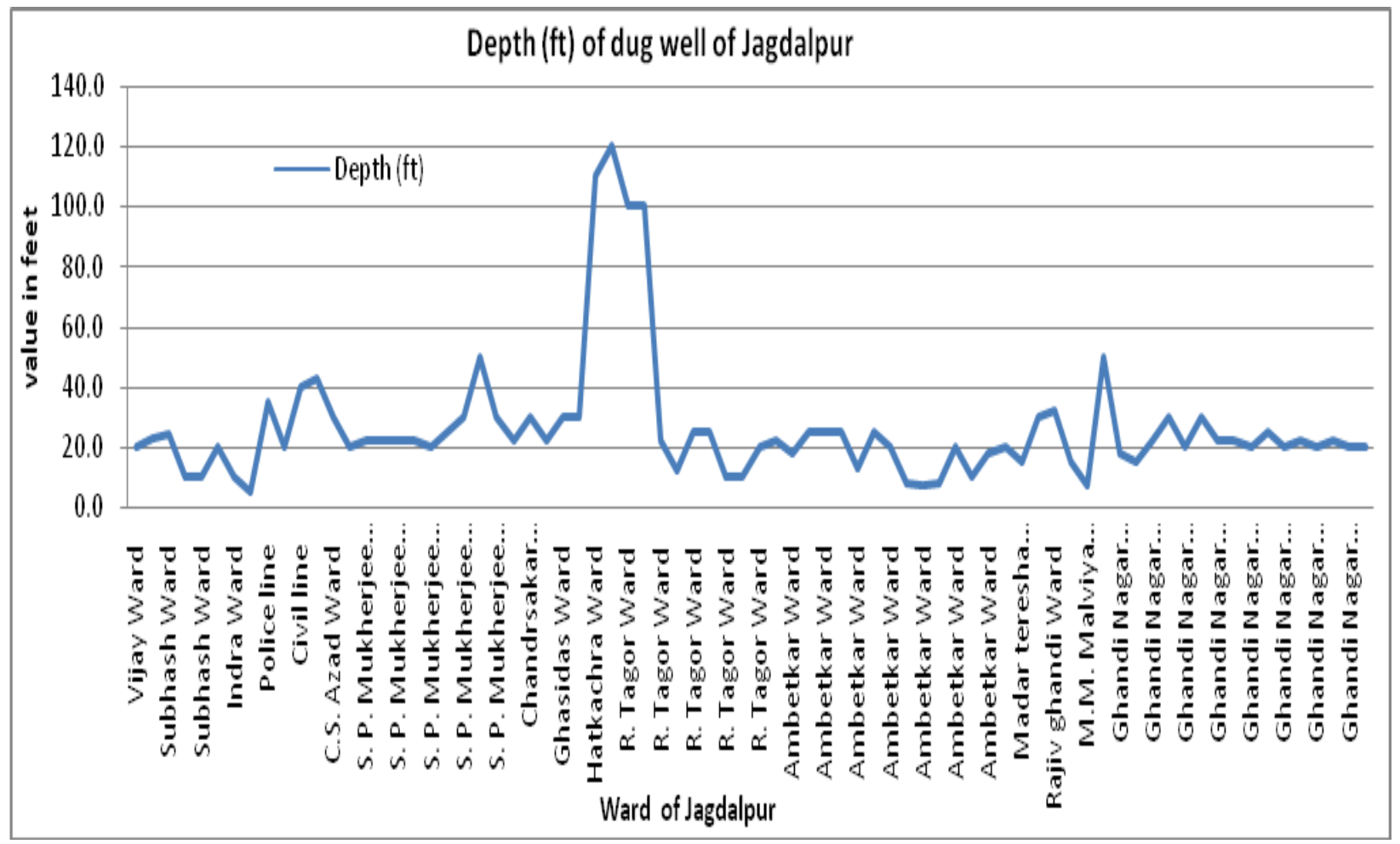

Fig.3 Ward wise water depth and table of bore wells at Jagdalpur city

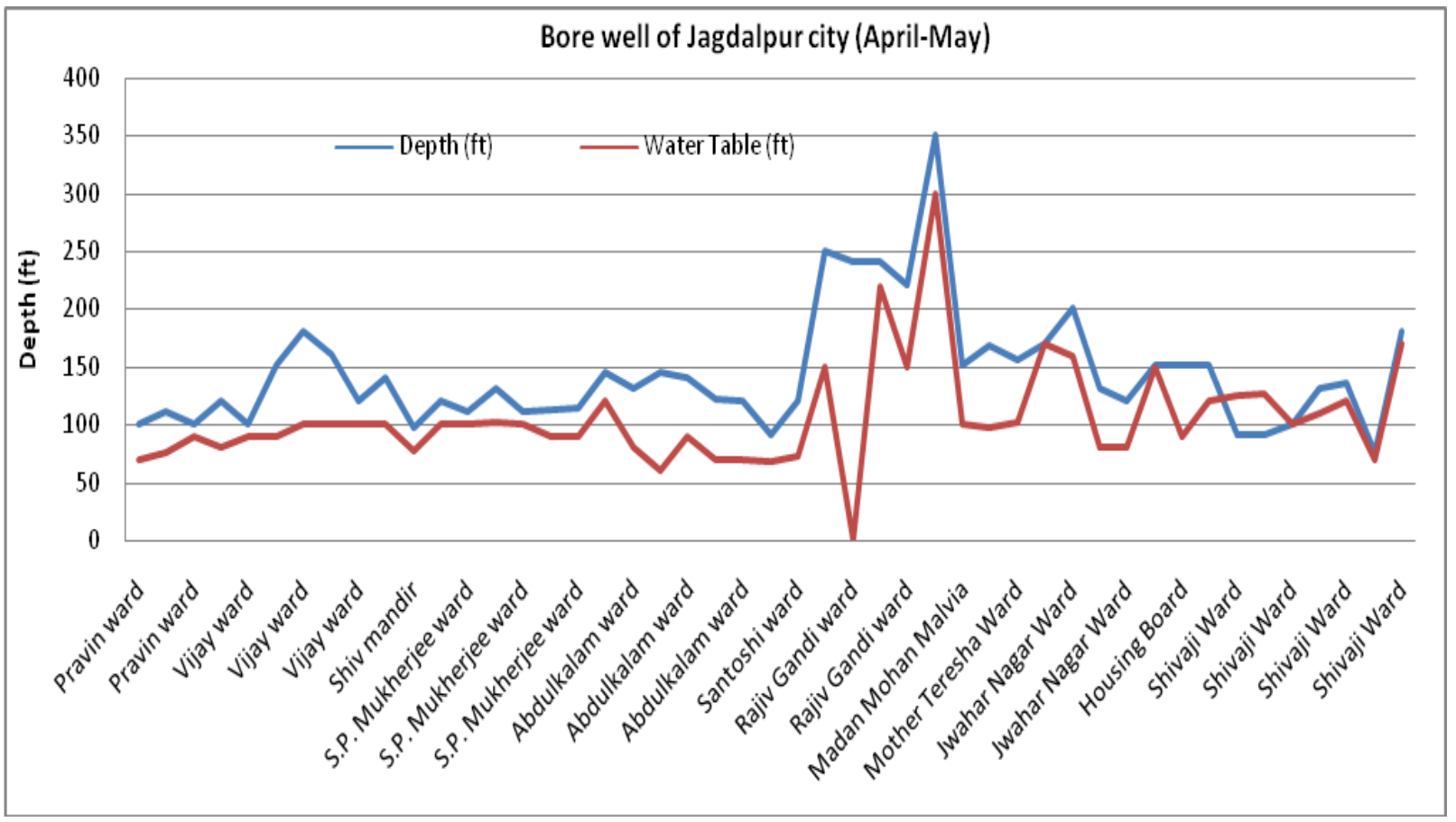


Photo.1 Shiv Temple of Dalpatsagar reservoir

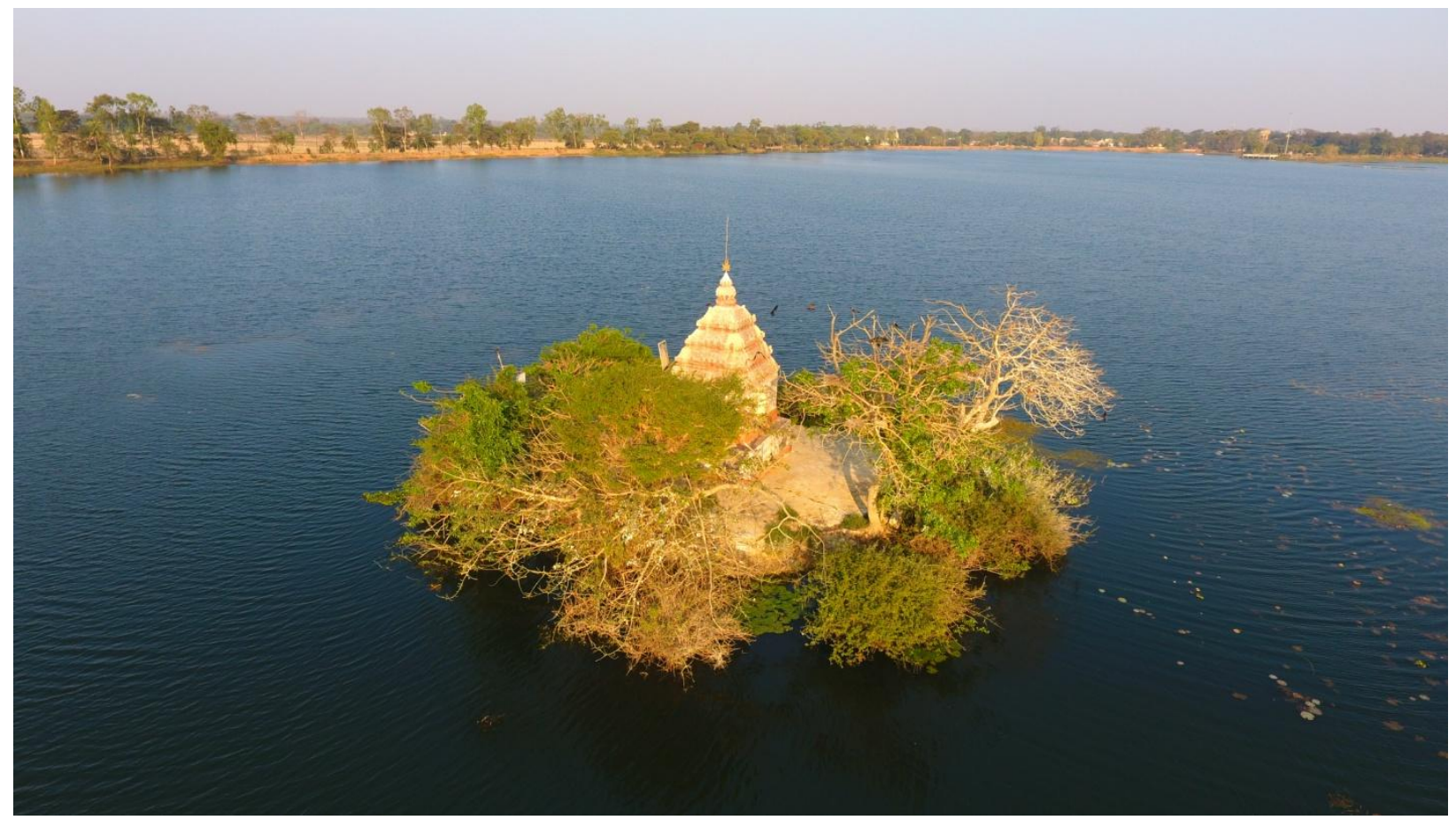

Photo.2 Catchment encroachment of Dalpatsagar reservoir

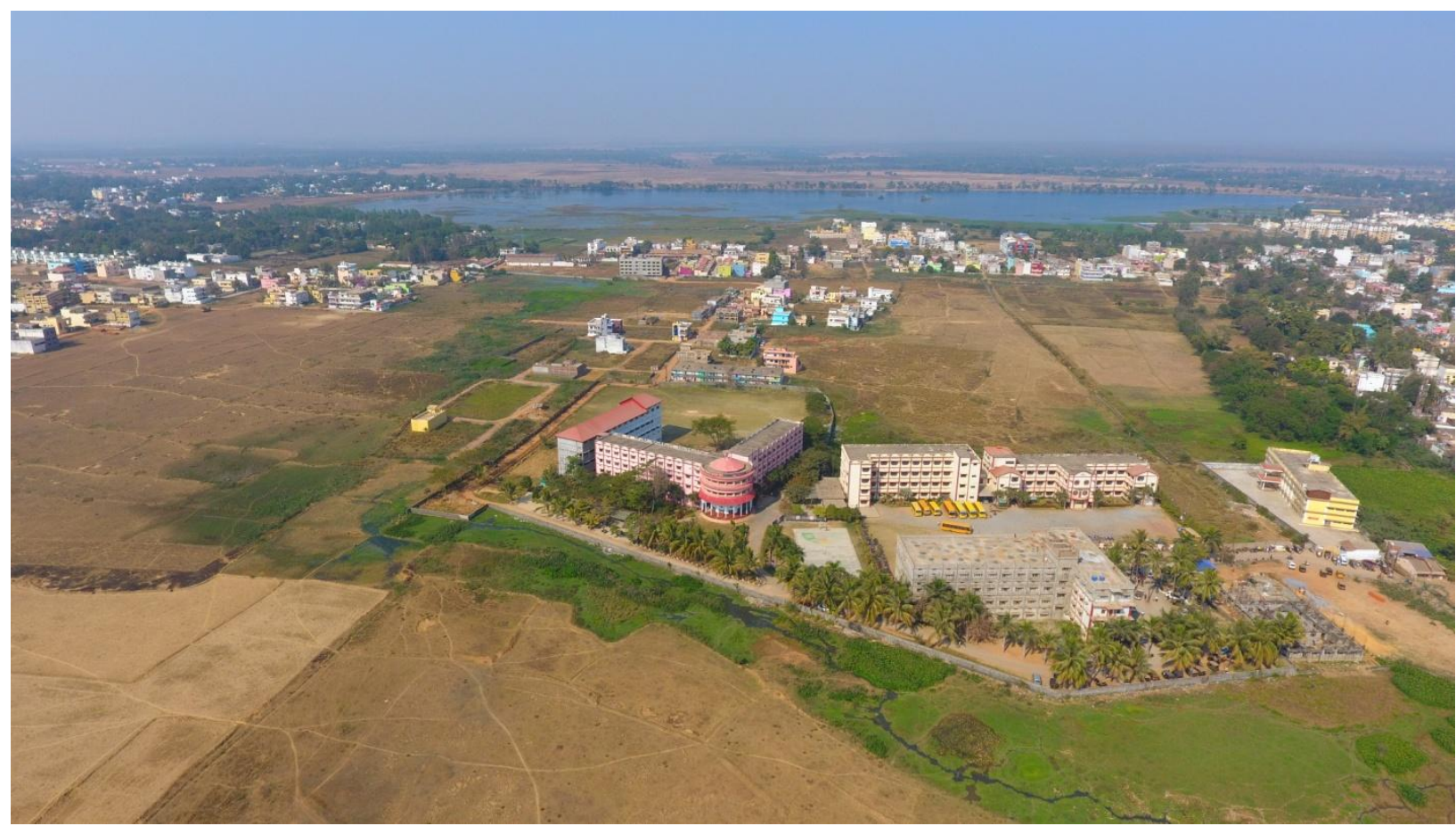


Photo.3 a. Avenue plantation on palace to Kalipur road, b. Water level observation in Reservoir, c. Runoff flow measurement from west weir and d. Sewage drain in Dalpatsagar

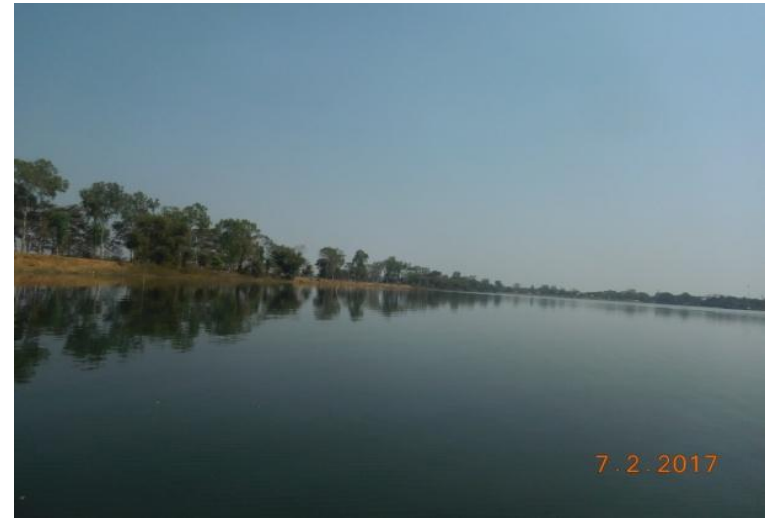

a.

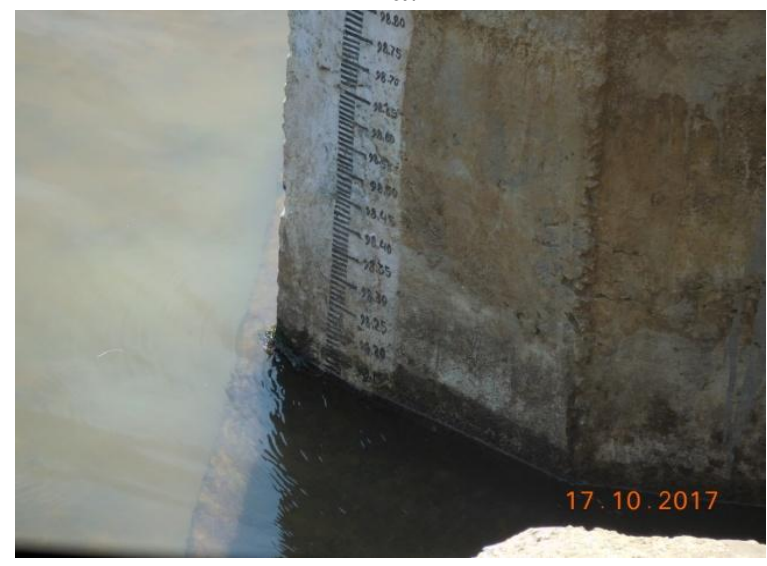

c.

Tube well depth at various locations of city and surrounding shows variability in water table according to geo-morphometric differences having quantum and pumping water change, which is basically depend on geology, catchment, population of the points while maximum depth was noted as 150 feet bgl with water table. Similar change was seen by Goswami (1985) in Brahmputra river system. Water table allows explaining 4\% variability in depth which was in between 100 to 150 feet bgl but linear trend highly variable around the line. Standard residuals versus depth of tube wells were also widely distributed in depth for pumping water, water table plotted against standard residuals was found between 80 to 100 feet $\mathrm{bgl}$, on other hand, predicted water table on standard

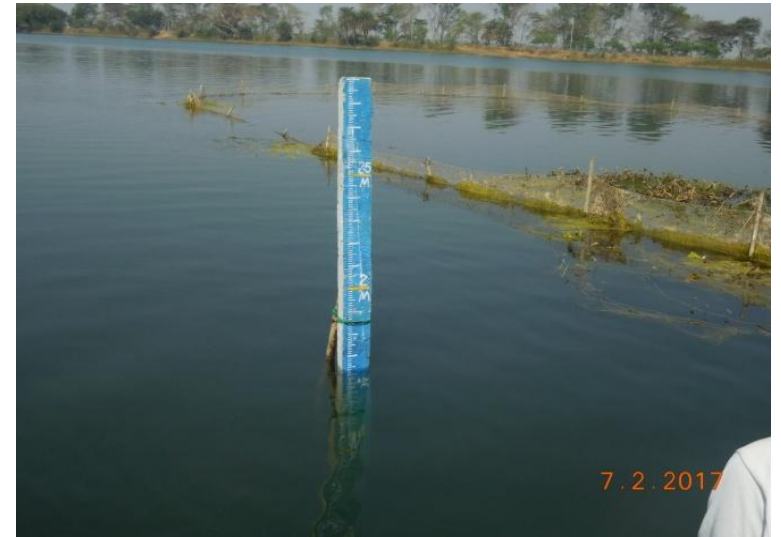

b.

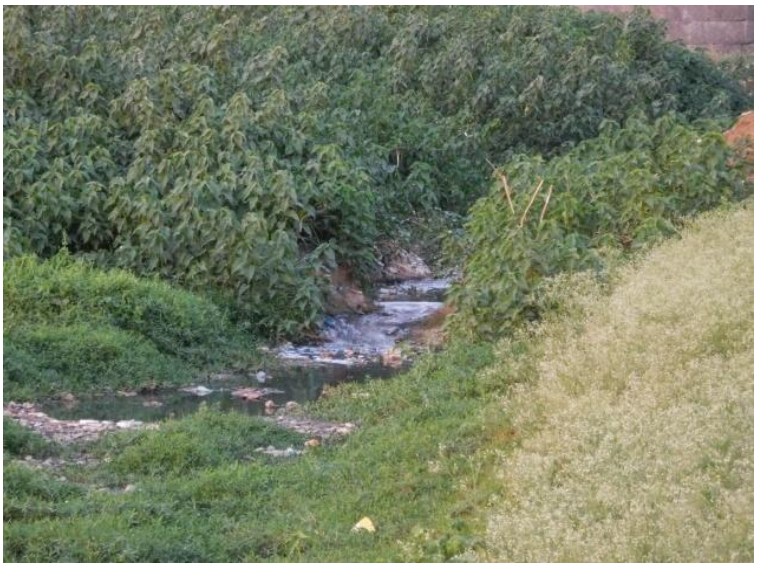

d.

residuals ranged negatively and positively in between 80 to 100 feet bgl i.e. pumping water at common depth of underground water range in the Jagdalpur city (Figure 1) while observation made during April-May might set common depth over the location, Panwar and Chakrapani (2013) suggested the way for recharge of wells and ground water. Dwindling of ground recharge also accelerated by diversion of natural flow as explained by Mishra et al., (2009) resulting drought phenomenon.

\section{Effect on water quality of reservoir}

Water quality was assessed the different quality parameters by sampling of water at 15 days interval on marked places, level and 
status of pollution are moderate and mesotrophic in character. Continuous monitoring of physio-chemical properties of Dalpatsagar reservoir showed much variation in parameters in last two years. Turbidity, $\mathrm{pH}$, conductivity, alkalinity, chloride, calcium, iron, biological oxygen demand, chemical oxygen demand were higher than allowable limit in August 2015 whereas nitrate, total hardness $\left(\mathrm{CaCO}_{3}\right), \mathrm{Mg}$, fluoride, sulphate, TSS, residual $\mathrm{Cl}$ and dissolved oxygen were less than allowable level during April 2016.

From June 2015 to January 2017 found reduction in value of total dissolved solid and EC due to dilution of rainwater into Dalpatsagar through runoff from catchment area. As in starting pH was 6.79 in June 2016 whereas 7.09 in January 2017, total dissolved solid in water was high in initial (2014) but decreased with rainwater mixing, similarly electric conductivity gone down slightly from 0.39 to 0.33 siemens per meter (Table 2).

Eutrophication is promoted by content of phosphorus in benthic zone; sewage draining area of reservoir had higher $\mathrm{P}_{2} \mathrm{O}_{5}$ in Old Naredra $(53.86 \mathrm{~kg} / \mathrm{ha})$ in soil followed by Balaji temple $(35.91 \mathrm{~kg} / \mathrm{ha})$ but recorded highest was recorded with sample collected from outlet of reservoir $(89.76 \mathrm{~kg} / \mathrm{ha})$ due to maximum deposition of detritus over remaining places of sampling which was similar in phosphorus content. Organic carbon percentage was recorded at 11 places at 15 days intervals varied as per location of reservoir from 0.68 to $6.09 \%$, sewage drain area (Old Naredra) had the highest organic carbon percentage followed by inlet of Moti Talab and rest were lesser. Inflow mixing into bottom, distance from edge and depth of water influences the nitrogen content into soil, inflow of rainwater and sewage entry were different in nitrogen content in soil samples, inflow places like Housing board (598.80 $\mathrm{kg} / \mathrm{ha})$, Balaji temple $(802.40 \mathrm{~kg} / \mathrm{ha})$ and old
Narendra sewage point $(850.30 \mathrm{~kg} / \mathrm{ha})$ were higher in $\mathrm{N}$ content and moving slight deeper the nitrogen was less in soil at Jhada tarae $(512.40 \mathrm{~kg} / \mathrm{ha})$. Mundra dhipka (650.00 $\mathrm{kg} / \mathrm{ha})$, Shiv temple (758.60 $\mathrm{kg} / \mathrm{ha})$ and Motitalab (764.80 kg/ha) were higher in nitrogen. Towards mud retailing wall in southern side slows down the flow of water showed less nitrogen content at Ram temple $(675.20 \mathrm{~kg} / \mathrm{ha})$ and Ranighat $(387.60 \mathrm{~kg} / \mathrm{ha})$. Range from littoral zone to benthic zone reduced nitrogen content from $850.30 \mathrm{~kg} / \mathrm{ha}$ at old Narendra to $387.00 \mathrm{~kg} / \mathrm{ha}$ and Baba Rakhwar (Table 3).

\section{Summary}

Among 121 dugwells, 60 as dirty water, 12 drying in pre monsoon period and 36 for drinking purpose were noticed under intensive observations. Maximum dugwells were recorded in Gandhnagar ward (17), followed by Dantewshari ward (15), Ambetkar ward (15) and Shyama Prasad Mukherjee ward (11) and Ravindrnath Tagore ward (9) in draining area of city watershed demarcated as recharge zone due to stagnation of water in two storage structures namely Dalpatsagar and Ganga Munda aligned in way of natural drainline. Total 63 tube wells were recorded in 48 wards and 17 feet was minimum in Ganga Nagar ward while 300 feet maximum in Mother Teresa ward with average depth found in 98.21 feet water table. Turbidity, $\mathrm{pH}$, conductivity, alkalinity, chloride, calcium, iron, biological oxygen demand, chemical oxygen demand were higher than allowable limit in August 2015 whereas nitrate, total hardness $\left(\mathrm{CaCO}_{3}\right), \mathrm{Mg}$, fluoride, sulphate, TSS, residual $\mathrm{Cl}$ and dissolved oxygen were less than allowable level.

\section{References}

ALPHA Standard Methods: For examination of water and waste water, $20^{\text {th }}$ ed. 
American Public Health Association, New York, USA, 115-124 (1998).

Annual Report, SGCARS, Jagdalpur. Kharif season rainfall data.1:5-8 (2016).

Annual Report: Ministry of water resource, River development and Ganga Rejuvenation, Government of India, 1821 (2016).

Annual Report, Municipal Corporation, Jagdalpur Chhattisgarh, 1(2):5-6(2011).

Bala, P., D. Gupta and Y.P. Sharma: Mycoflora and natural aflatoxin contamination in dried quince seeds from Jammu, India. J. Environ. Biol., 37, 101-106 (2016).

Buchanan, C: Ground Water Quality and Quantity Assessment. J. Ground Water., 193-200 (1983).

Cataldo D. A., M. Maroon, L. E. Schrader and V. L. Youngs: Rapid colorimetric determination of nitrate in plant tissues by nitration of salicylic acid. Commun. Soil Science and Plant Analysis 6(1)7180 (1975).

Datta, P. S. and S. K. Tyagi: Major ion chemistry of groundwater in Delhi area: chemical weathering processes and groundwater flow regime. J. Geol. Soc. India., 47, 179-188 (1996).

Devito K., Creed I. and Fraser C: Controls on runoff from a partially harvested aspenforested headwater catchment, Boreal Plain, Canada. Hyrdol Process 19:3-25 (2005).

Eriksson, M., X. Jianchu, A. B. Shrestha, R. A. Vaidya, S. Nepal, and K. Sandstrom: The changing Himalayas impact of climate change on water resources and livelihoods in the greater Himalaya. Kathmandu: International Centre for Integrated Mountain Development (ICIMOD) (2009).

Fleig, A.K., L.M. Tallaksen, H. Hisdal, S. Demuth: A global evaluation of stream flow drought characteristics. Hydrol. Earth Syst. Sci. 10 (4), 535-552 (2006).
Ghosh, S., and S. Dutta.: Impact of climate change on flood characteristics in Brahmaputra basin using a macro-scale distributed hydrological model. Journal of Earth System Science, 121, 637-657 (2012).

Goswami, D. C.:Brahmaputra river, Assam, India: Physiography, basin denudation, and channel aggradation. Water Resources Research, 21, 959978(1985).

Jackson M.L: Soil chemical analysis. Prentice Hall of India Pvt. Ltd., New Delhi:498 (1954).

Kundzewicz, Z. W., L. J. Mata, N. W. Arnell, P. Do 1l, P. Kabat, B. Jimenez, and M. J. Scott: Climate change 2007 - the physical science basis, science. Cambridge: Cambridge University Press (2007).

Laghari, A. N., D. Vanham, and W. Rauch: The Indus basin in the framework of current and future water resources management. Hydrology and Earth System Sciences., 16, 1063-1083 (2012).

Marothia, D.K:Fish Farming in Small Multiuse water bodies: water sharing mechamism and its implications, In Vass, K.K., Sarangi,N. Mitra, K. Jena, J.K. Suresh, V.R. Shrivastava, N.P. and Katiha, P.K. (Eds.). Water Management in Fisheries and Aquaculture, Inland Fisheries Society of India, Barrackpore, W.B. and Association of Aquaculturists, Bhubaneswar, Orissa. pp. 151-159 (2007).

Mishra, A., V. Singh, V. Desai: Drought characterization: a probabilistic approach. Stochastic Environ. Res. Risk Assessm., 23 (1), 41-55 (2009).

Nyabeze, W.R.: Estimating and interpreting hydrological drought indices using a selected catchment in Zimbabwe. Phys. Chem. Earth, 29(15-18), 1173-1180 (2004). 
Olsen S.R., C.V., Cole T.S. Watanable, L. A. Dean: Estimation of available phosphorus in soil extraction with sodium carbonate. USDA, Wasington (1939).

Panwar, S. and G. J. Chakrapani: Climate change and its influence on groundwater resources. Curr. Sci., 105, 37-46 (2013).

Planning Commission Five Year Plan.http://planningcommission.gov.in/ plans/planrel/fiveyr/12th/pdf/12fyp_vol 1. pdf. Hanson, R.T., Flint, L.E., Flint, A.L., Dettinger, M.D., Faunt, C.C., Cayan, D., Schmid, W., 2012. A method for physically based model analysis of conjunctive use in response to potential climate changes. Water Resource. Res. 48, W00L08. http://dx.doi.org/10.1029/2011WR0107 74 (2013).

Redding T. and Devito K: Aspect and soil textural controls on snowmelt runoff on forested Boreal Plain hillslopes. Hydrol Res 42:250-267(2011).
Rossmiller, R.L: The Rational Formula Revisited. Proceedings of the International Symposium on Urban Storm Runoff, University of Kentucky, Lexington, KY, July 28-31 (1980).

Sangodoyin, A.Y., M.R. Brieger, M.J. Ayotamuno, M.K. Sridhar, P. Vyne: Shallow Drum Lined Wells for guinea worm Eradication. Waterlines, 2(11), 911 (1990).

SODIS News. Editorial Nos. I and 10; Todd. K: Groundwater Hydrology. Published by John Wiley \& Sons, New York Chichester, 2nd Edition (1997).

Van der Kamp G., Hayashi $\mathbf{M}$ and Gallen D:Comparing the hydrology of grassed and cultivated catchments in the semiarid Canadian prairies. Hydrol Process 17: 559-575(2003).

Walkley A. and Black I.A: An examination of Degtjareff method for determining soil organic matter and a proposed modification of the chromic acid titration method. Soil Sci. 37: 29-37 (1934).

\section{How to cite this article:}

Adikant Pradhan, S.K. Patil, D.K. Marothia, T. Chandrakar, S.K. Nag and Mukherjee, S.C. 2019. Effect of Catchment and Hydrology of Ancient Dalpatsagar Reservoir on Water Resources of Jagdalpur City, Bastar, India. Int.J.Curr.Microbiol.App.Sci. 8(01): 1797-1812. doi: https://doi.org/10.20546/ijcmas.2019.801.191 